\begin{tabular}{rr} 
çağdaş & Yaratıcı Drama Dergisi 2017, 12(1), 87-104 \\
drama & www.yader.org \\
\hline
\end{tabular}

\title{
Yaratıcılık Engellerinin Yaratıcı Drama ile Fark Edilmesine Yönelik Bir Araştırma*
}

\author{
Gökhan Karaosmanoğlu' ${ }^{1}$
}

Ömer Adıgüzel ${ }^{2}$

\begin{tabular}{|c|c|c|}
\hline \multicolumn{2}{|c|}{ Makale Bilgisi } & Öz \\
\hline \multicolumn{2}{|c|}{ DOI: $10.21612 /$ yader.2017.005 } & Bu çalışmanın amacl, ögrencilerin yaratıcıllı̆̆ engelleyen etmenleri öğrenmelerinde \\
\hline \multicolumn{2}{|c|}{ Makale Geçmişi } & Çalışmada nicel ve nitel araştırma yöntemlerinin bir arada olduğu karma yöntemlerden \\
\hline Geliş tarihi & 08.12 .2016 & $\begin{array}{l}\text { birleşik desen kullanılmıștır. Araştırmanın çalışma grubunu 2012-2013 öğretim yılında } \\
\text { ögrenim görmekte olan 6. sınıf örencileri olusturmaktadır. Nicel ve nitel veriler }\end{array}$ \\
\hline Düzeltme & 10.01.2017 & seçkisiz olmayan örnekleme yöntemlerinden amaçsal örneklem yardımıyla seçilen \\
\hline Kabul & 28.05 .2017 & $\begin{array}{l}\text { araştırma gurubundan elde edilmiştir. Veri toplamak amacıyla, öğrenci ürünleri } \\
\text { (mektup, poster, afiş, yazılı ürünler), her oturum sonunda ögrencilere yöneltilen } \\
\text { açı uçlu sorular ve kavram listesi kullanılmıștır. Öğrencilerin yaratıcıllkların }\end{array}$ \\
\hline \multicolumn{2}{|c|}{ Anahtar Sözcükler } & engelleyen etmenler göz önünde bulundurularak okul, aile, çevre/toplum, teknoloji, \\
\hline \multicolumn{2}{|c|}{ Yaratıcılık } & $\begin{array}{l}\text { kişisel özellikler gibi bassllklar belirlenmiş ve bu basslıklara uygun yaratıcı drama } \\
\text { etkinlikleri kurgulanmıstır. Calısmada elde edilen veriler betimsel analiz ve SPSS }\end{array}$ \\
\hline \multicolumn{2}{|c|}{ Yaratıcılık engelleri } & programı kullanılarak analiz edilmiştir. Çalışmadan elde edilen bulgular ışığında, \\
\hline \multicolumn{2}{|c|}{ Yaratıcı drama } & $\begin{array}{l}\text { ögrencilerin yaratıcılı engellerini ögrenmelerinde ve farkındalık kazanmalarında } \\
\text { kullanılan yaratıcı drama yönteminin etkili olduğu görülmüştür. Elde edilen bulgular, } \\
\text { yaratıcı drama yönteminin öğrencilerin kendilerini ifade etmelerinde, hayal güçlerini } \\
\text { ve yaratıcılıklarını etkin bir biçimde kullanmalarında etkili olduğunu göstermektedir. }\end{array}$ \\
\hline
\end{tabular}

\section{A Reseach Toward Awarenes of Creativity Barriers with Creative Drama}

\begin{tabular}{lr}
\hline Article Info \\
\hline DOI: $10.21612 /$ yader.2017.005 \\
\hline Article History & \\
Received & 08.12 .2016 \\
Revised & 10.01 .2017 \\
Accepted & 28.05 .2017
\end{tabular}

Keywords

Creativity

Creativity barriers

Creative drama

\begin{abstract}
The purpose of this study is to examine the role of creative drama on students' learning of creativity barriers and in raising awareness. In the study a mixed method in which quantitative and qualitative research methods are combined is used. The research group of the study is the 6th grade students who are studying in the 2012-2013 school year. Quantitative and qualitative data were obtained from the research group which is selected through purposive sampling,one of the non-random sampling methods. In order to gather data, student products (letters, posters, posters, written products), open ended questions and concept list directed to the students at the end of each study were used. Creative drama is used as a method in the study. The topics such as school, family, environment / society, technology, personal characteristics were determined and creative drama activities were designed according to the factors that prevent the creativity of the students. The data obtained in the study were analyzed using descriptive analysis and SPSS program. In the light of the findings obtained from the study, it is seen that the creative drama method used for students to learn the creativity barriers and to gain awareness is effective. The findings show that creative drama is effective on students' expressing themselves and effectively using their imagination and creativity.
\end{abstract}

\footnotetext{
Bu makale, MEB Özel Doğaç Yaratıı Drama Liderliği/Eğitmenliği Kursu Bitirme Projesi’nden Geliştirilerek Yazılmıştır. Öğretmen, Milli Eğitim Bakanlı̆̆ı, E-posta: gkaraosmanoglu@gmail.com

2 Prof. Dr. Ankara Üniversitesi Eğitim Bilimleri Fakültesi, E-posta: omeradiguzel@gmail.com
} 


\section{Giriş}

\section{Yaratıcılık ve Yaratıcı Düşünme Süreci}

Toplumların ilerlemesini ve gelişmesini sağlayan yaratıcılık, bilimsel buluşların ve keşiflerin, sanatsal etkinliklerin ve ürünlerin ortaya çıkmasında önemli rol oynamaktadır (Senemoğlu, 1996). 21. yüzyılda toplumlar, bireyler, eğitim kurumları, demokratik gelişim, ekonomi ve günlük yaşam pratikleri adına vazgeçilmez bir öneme sahip olan yaratıcılık; uyum gösterme, esneklik, girişimci olma ve bilgiyi şimdiye kadar elde edilmiş olanlardan farklı biçimlerde kullanma ve dönüştürme süreci açısından oldukça önemli bir gereksinimdir (Burnard ve White, 2008).

Yaratıcılık her insanın doğuştan sahip olduğu, yaşamın her alanında var olan ve geliştirilebilen bir beceridir (Püsküllüoğlu, 2012; Tekin Bender, 2014), ancak bu beceriyi duyarlı bir yaklaşımla ve sağlıklı bir biçimde geliştirmek için öncelikle yaratıcılığın gerçek doğasını, ne olup ne olmadığını anlamak gerekmektedir (Robinson, 2008).

Yaratıcı olma durumu, yaratabilme, var edebilme yeteneği olarak tanımlanabilen (Püsküllüoğlu, 2012) yaratıcılık; doğurmak, yaratmak, meydana getirmek (San, 2012) anlamına da gelmektedir. Kişiden kişiye farklılık gösteren yaratıcılık kavramına ilişkin pek çok farklı tanımlama, genellikle kişilerin farklı özelliklerine odaklanmaktadır. Tanımlanması çoğunlukla güç olan yaratıcılık; bir tutum, bir süreç, bir ürün, bir beceri, kişilik özelliklerinin birleşimi ya da çevresel koşulların bir sonucu olarak ortaya çıkabilir (Fox ve Schirrmacher, 2012).

Yaratıcılık bir şeyi yoktan var etme süreci değil; varlığını sanat, bilim gibi yaratıları ile yaşamı etkileyen insanların ayırt edici, özgün özelliklerinden alan (Baykal, 2009), imgelerle ve mantıksal çıkarımlarla düşünme sürecidir. Yaratıcılık sürecinde önceden kazanılmış bilgiler kullanılsa da, ortaya çıkan/beliren eski deneyimlere yenilerin eklendiği bir "yapma ve oluş" sürecidir. Değişimi ifade eden bu oluş süreci şimdiye dek olmayan bir şeyin biçimlenmesi anlamına gelir (San, 2012).

Sıklıkla sanat, bilim ve teknikle özdeş kabul edilen yaratıcılık, yalnızca müzik ve resim gibi belirli sanat alanlarında değil, insan tarafından tamamlanmış her işte, yaşamın her anında ve insanın her eyleminde kendini var edebilir (San, 2004; Robinson, 2008). Varlığı ortaya çıkarma süreci olan yaratıcılık, sanatçının olduğu kadar bilim insanının, düşünürün emeğinde görülmelidir; bazen annenin çocuğuyla normal ilişkilerinde ortaya çıkan yaratıcılık, bazen de kişilerin günlük yaşam deneyimlerinde kendini gösterir (May, 2010).

Hem estetik hem de otantik özellikler içeren, yeni bir şeye varlık kazandırma süreci olan yaratıcılık (May, 2010), ister sanatçı ister sıradan bir insan olsun, bireyin yaratıcı düşünceyle ilk temasını oluşturan karşılaşmayı barındırır. Sanat alanında iki farklı tür yaratıcılıktan söz edilebilir: Bunlardan ilki resim yapma, müzik besteleme, roman ya da şiir yazma gibi yeteneğe bağl1, öğrenilebilen ve alıştırmalarla geliştirilebilen becerilerdir. Bu beceriler aynı zamanda ürün veren yaratıcı etkinliklerdir. İkincisi ise her tür yaratıcılığın temelinde bulunan, yaratıcı tutum ve davranış biçimidir. Bu yaratıc1lık bir ürünle görünür duruma gelmeyebilir. Aynı zamanda görme, algılama ve tepki verme (San, 2004) gibi farklı biçimlerde ortaya çıkabilen yaratıcılık bir karakter özelliğidir. Sözgelimi Freud, Picasso gibi kişiler büyük yaratıcılardır, evinde akşam yemeği veren kişilerin yemeği servis etme biçimleri günlük yaratıcılıktır, sosyal etkinliklerde şiir okuma, bir metni yaratıcı okuma gibi davranışlar küçük yaratıcılık olarak ortaya çıkar (Gardner, 2009). 
Torrance yaratıcılığı “Boşlukları, rahatsız edici ya da eksik ögeleri sezip, bunlar hakkında düşünceler geliştirmek, varsayımlar kurmak, bunları sınamak, sonuçları karşılaştırıp değiş̧tirmek ve yeniden sınamaktır" biçiminde tanımlarken, Landau yaratıcı süreçlerde bireylerin daha önceden kurulmamış ilişkiler arasında bağlantılar kurduklarını, böylelikle yeni yaşantılar, deneyimler, düşünceler ve ürünler ortaya koyduklarını ifade etmektedir (San, 2004, s.14-15). Yaratıcılık bazen değişik bakış açılarıyla bakabilme ve verilen sınırların dışına çıkabilme becerisi, bazen özgün bir ürün tasarlama ve geleneksel yolların dışında düşünme bazen de birbiriyle ilgisiz gibi görünen şeyleri yeni bir biçim yaratmak için bir araya getirmektir (Fox ve Schirrmacher, 2012). Yaratıcılık farklı alanlardaki nesneleri, bilgileri ya da düşünceleri bir araya getirir; görünmeyeni görünür yaparak, imgelerle ya da mantıksal çıkarımlarla farklı bir biçim ortaya koyar. Araştırmacıların üzerinde durduğu en önemli nokta "ortaya yeni ürünler koyma becerisi", başka bir deyişle "boşlukları tamamlama" olarak tanımladıkları yaratıcı düşünmedir.

Yaratıcılık ve yaratıcı düşünme bazen aynı kavramlar olarak algılansalar da farklıdır. Sorunlara, bozukluklara, uyumsuzluğa karşı duyarlı olma, çözüm arama ya da eksikliklere karşı tahminlerde bulunma biçiminde gerçekleşen yaratıcı düşünme (Pars1l, 2012), temelinde özgün ve esnek düşünebilmeyi, sorunlara hızlıca ve farklı bakış açılarından çözümler üretmeyi gerektirir. Zihinsel bir süreç olan yaratıcı düşünme günlük yaşamın pek çok anında karşımıza çıkarken; yaratıcılık, zihinsel sürecin yanında bir performans, bir ürün de gerektirir. Yaratıcılık aynı zamanda hazırlık, kuluçka, aydınlanma ve gerçekleme-doğrulama-değerlendirme aşamalarını da içerir (Sungur, 1997).

Özerklik ve bağımsız hareket etme yaratıcı düşüncenin ortaya çıkmasında oldukça etkiliyken, var olana uyma ve körü körüne itaat etme bu süreci olumsuz etkileyen durumlardır (Baykal, 2009). Yaratıcılık olaylara ve nesnelere farklı bir pencereden (kutunun dışından), farklı bakış açılarıyla, toplumsal ve kültürel ölçütlerin dışından bakmayı, değerlendirmeyi gerektirir. Bu özelliğiyle var olanı, toplumsal ya da kültürel olanı, gelenekseli reddeder; özgün ve sıra dışı biçimleri keşfetmeye gereksinim duyar. Yaratıcı olan kendisini özgür, güvende ve bağımsız hissetmek ister (Rogers, 1976; Sungur, 1997); ailevi ya da toplumsal engeller, eğitsel ya da kültürel kalıplar, kişisel ya da toplumsal önyargılar yaratıcı düşüncenin önünde duran bariyerlerdir.

Çocukların yaratıcı düşünceyle tanışması ve bunu çeşitli biçimlerde ifade etmesi yaşamın ilk zamanlarında başlar. Doğuştan getirilen ve bebeklikten itibaren karalamalarla başlayan, yaşamın ilk yıllarında yüksek seviyelere ulaşan yaratıcılık desteklenip geliştirilebilecek bir beceridir (Kara ve Şençiçek, 2015). Zihinsel bir süreç olmanın yanında duyular ve duyumlar, imgeler ve imgelem gücü gibi beceriler ve bunların birbirleriyle bağlantıları olan yaratıcı düşünme, tüm bu alanları birleştirerek örgütleyen ve ortaya bir yenilik koyan, imgelerle düşünme sürecidir. Bireyin hayal gücünü kullanmasıyla ortaya çıkan, özgür kaldığında ve spontan (kendiliğinden) davrandığında kendisini daha nitelikli ifade ettiği yaratıcı düşünme süreci, sanılanın aksine yalnızca zekâyla değil, aynı zamanda duyularla, duygularla ve sezgilerle ilgilidir. Duyularını etkin bir biçimde kullanan bireyler algıladıkları ve duyumsadıkları bilgilerin ötesine geçerler; bu bilgileri hayal güçleriyle ve yaratıcılıklarıyla birleştirirler. 


\section{Yaratıcılığın Önündeki Engeller}

Kişilerin kendisinden, ailesinden ve okulundan kaynaklı pek çok durum yaratıcılığını engelleyebilir. Problem çözme sürecinin ilk adımı olan problemi fark etmek ya da tanımlamak yaratıcılığın ortaya çıktığı süreç için de geçerlidir. Yaratıcılığı geliştirmenin ilk basamağı da yaratıcılığın önündeki engelleri belirlemek ve bu engelleri tanımlamak olacaktır (Dursun ve Ünüvar, 2011).

Öğrenciler öğrenme süreçlerinde yaratıcılıklarını ve hayal güçlerini kullanarak kendilerini ifade etmeye çalışsalar da eğitim dizgelerinin yaratıcılıktan yoksun olduklarını ve öğrencilerin yaratıcılıklarına katkı sağlayamadıklarını söylemek yerinde olacaktır (Ataman, 1995; Üstündağ, 2014). Çocuklar doğal olarak yaratıcıdır, ancak ailelerinin sert disiplin kurallarını kabul ettiklerinde ve eğitim almaya başladıklarında, yaratıcılık yetilerini kaybetmeye başlarlar (Herrmann, 2003). İnsanların sorunlar karşısında bir tek çözüm yolunu görmelerini ve diğerlerini dikkate alamamalarına neden olan yakınsak (dikey) düşünme, yaratıcılığın önündeki bir diğer engeldir; yakınsak düşünen bireyler yetiştirme eğiliminde olan geleneksel eğitim dizgeleri ıraksak düşünme ve yaratıcı yetinin zamanla körelmesinde pay sahibidir (San, 2003; Üstündağ, 2014).

Çoğunlukla uyumlu ve yakınsak düşünen bireyler yetiştirmeye odaklanan okullar, çocukların kendilerini kapana kısılmış hissettikleri ve hareket edemedikleri, kendilerini ifade etme olanaklarının kısıtlı olduğu mekânlar haline dönüşebilir (Çalışmaya katılan çocuklardan biri okulu; kapısında bir bekçinin olduğu, öğretmenlerin ve yöneticilerin kendilerine zorla eğitim vermeye çalıştıkları modern bir hapishaneye benzetmiştir). Toplum yalnızca eğitim ve aile kurumlarıyla değil, bazen de toplumsal ve kültürel kurallarla, geleneklerle ve adetlerle; bir takım davranış kalıplarını, değerleri ve tavırları çocuklara dayatarak yaratıcılığın önünde bir engel olarak durmaktadır. Bu bazen çocuklara basmakalıp davranışları dayatarak bazen de cinsiyet rollerini kabul etmeye zorlayarak, onlardan farklı bireyler olmalarını bekleyerek gerçekleşir.

Merak duyan ve düş kuran, imgelerle düşünebilen, sabırla yaptığı işi sonuçlandırmak isteyen, deney ve araştırmalar yapmaya hevesli kişiler olan çocukların (San, 2004; Baykal, 2009; Üstündağ, 2014), yaratıcı ve hayal gücü yüksek bireyler olmaları için soru sormaları ve öğrenmeye istekli olmaları gerekir. Çocuklar bir yandan çevreyi keşfetmeye ve yaşama uyum sağlamaya çalışırken diğer yandan toplumun, özellikle anne-babanın, olumlu ya da olumsuz etkisiyle karşılaşır. Belirli bir yaşa kadar bireyin yaratıcılığını etkileyen anne-baba, yerini zamanla okula, akran gruplarına, teknolojiye ve eğitim sistemine bırakır. Çocuk, yaşamını sürdürdüğü evde bazen televizyonun önünden çekilmesi gereken bir nesne, bazen çok soru sorup evdekilerin canını sıkan bir çokbilmiş, bazen de gereksiz konulara yoğunlaşan, susması ve büyükler dünyasında, "Sen ne zaman büyüyeceksin?" sorularına maruz kalan, büyümek zorunda olan bir varlık durumuna düşebilir.

Destekleyici çevre ve aile faktörleri yaratıcılığı olumlu biçimde etkilerken, olumsuz koşullar yaratıcılığı kısıtlayabilir. Ev, okul, cinsiyet rolleri, toplum, kültür ve geleneklerin yaratıcılığın önündeki potansiyel engeller olarak söylenebilir (Fox ve Schirrmacher, 2012). Otoriter, sınırlar koyan aileler çocuklardan gerçekleştirilmesi güç taleplerde bulunabilirler ya da çocukların davranışlarını garip, olgunluk göstermeyen, anormal ve haylaz olarak algılayıp çocukların yaptıklarını yaramazlık olarak tanımlayabilirler. 
Yetişkinlerin yaptıkları hatalardan biri de çocuklara kendi deneyimlerini yaşamalarına olanak tanımamalarıdır. Düş kurmak, kendi oyunlarını tasarlamak ve yeni şeyler keşfetmek isteyen çocukların, bu süreçleri yaratıcı bir biçimde yaşamalarına engel olmak yaratıcı düşünmelerine de engel olmak anlamına gelmektedir (Üstündağ, 2014). Bilinçli bir biçimde ya da farkında olmadan ortaya konan bu davranışlar, çocukların yaratıcılıklarını ve hayal güçlerini ifade etmelerine engel olur. Çocuklar; problem çözebilen, çevresiyle uyumlu, yaratıcı, kendini gerçekleyebilen, mutlu, sağlıklı bireyler yerine anne-babalarına bağımlı, sürekli yardım bekleyen ve özgüvensiz kişiler haline gelebilirler.

Bireyin kendi kişisel rahatına düşkünlügü̈, içsel özgürlükten yoksun olma, yanlış yapmaktan ya da alay edilmekten korkma, hırs (en iyi olma tutkusu), çevre-toplum-aile baskısı (San, 2003; Üstündağ, 2014; Kara ve Şençiçek, 2015), konformizm (uyguculuk) ve konvensiyonalizm (uylaşımcılık) (San, 2012) çocukların her an karşılarına çıkabilen ve yaratıcılıklarının önünde bir engel olarak durabilen etmenler arasında sayılabilir. Sungur (1997)'a göre yaratıcıllğın önünde kendine güvensizlik, hata yapma ve eleştirilme korkusu gibi bireysel engeller, geriye dönük tutumlar, önceden ve sürekli özeleştiri gibi örgütsel engeller ve önyargılar, atasözleri, tabular gibi toplumsal engeller de bulunmaktadır.

Öğrencilerin yaratıcılıkları aile, toplum, teknoloji, gelenekler ve çevresel etkenler tarafından olumsuz yönde etkilenirken, öğrenciler eğitim sistemindeki sınav, ders yükü, akademik başarı beklentisi gibi olumsuz etkenler nedeniyle zamanla yaratıcılıklarını kaybetmektedirler. Bu durum görme, işitme, dokunma gibi duyularını tam anlamıyla keşfedemeyen, çevresindeki dünyayı fark edemeyen, bir şeyleri değiştirmeye kalkışmayan, problemlerini kendisi çözmek yerine çevresinden yardım bekleyen öğrencilerin yetişmesine neden olmaktadır.

$\mathrm{Bu}$ etmenlerin tümü çocukları aynı oranda etkilemez. Çocukların yaşantıları ve içinde büyüdükleri şartlar etkilenme düzeylerini değiştirmektedir. Güven ve özgürlük gereksinimi de bireyin yaratıcılığını önemli derecede etkilemektedir. Rogers (Akt. Sungur, 1997)'a göre bireyin güven ve özgürlük gereksiniminin karşılanması yaratıcılığını artırırken, bireyin bu iki durumdan yoksun bırakılması, tam tersine yaratıcılığına ve hayal gücüne ket vurulması anlamına gelmektedir.

\section{Yaratıcılığın Önündeki Engeller ve Yaratıcı Drama}

Yaratıcı drama, "Bir grupla ve grup üyelerinin yaşantılarından yola çıkarak; bir amacın, düşüncenin, doğaçlama, rol oynama (rol alma) vd. tekniklerden yararlanarak canlandırılmasıdır” (Adıgüzel, 2014, s.45). Oyunun genel özelliklerinden yararlanan yaratıcı drama kendiliğindenlik (spontanite), şimdi ve burada ilkesi, -mış gibi yapma gibi özelliklere sahiptir ve yaratıcı drama çalışmaları bir eğitmen eşliğinde yürütülür.

Yaratıcılık süreci ve yaratıcı drama pek çok alanda ortaklaşmaktadır. Yaratıcı drama süreçleri de hazırlık-1sınma, canlandırma ve değerlendirme süreçlerini içerir ve bu süreçlerde bir fikrin, bir konunun ya da bir kazanımın gerçekleşmesi, ortaya çıkması beklenir. Söz konusu süreçler için kendiliğindenlik (spontanite) oldukça önemli bir yere sahiptir. Kendiliğindenlik yaratıcı drama süreçlerinin her aşamasında bulunur (Üstündağ, 2014). Yaratıcı drama da benzer bir biçimde her insanın doğuştan az ya da çok yaratıcı olduğunu ve bu yaratıcılığın uygun ortamlarda geliştirilebileceğini savunur. Yaratıcı drama bireyin imgelem dünyasını, duyularını kullanma ve sorun çözme becerisini geliştirir, hayal gücünü kullanarak daha yaratıcı bir birey olmasına olanak 
sağlar. Bu açıdan bakıldığında yaratıcı drama hem bireylerin yaratıcı olmalarında hem de yaratıcılığı engelleyen etmenleri fark etmelerinde oldukça önemli bir yere sahiptir.

Yaratıcılık, yaratıcı drama çalışmalarının özellikle canlandırma aşamasında kendini gösterir ve bu süreçler yaratıcı bireyin, yaratıcı düşüncenin ortaya çıkmasında etkili olur. Bireyin imgelem dünyasının, düş gücünün harekete geçtiği canlandırma aşaması yaşantılardan ya da deneyimlerden yola çıkarak, gerçekle kurgu arasında bağlantı kurulmasını ve bireyin kendi yaşamına farklı bir açıdan bakmasını sağlar. Yaratıcı dramanın ve yaratıcılığın en önemli buluşma noktasının hayal gücü olduğu söylenebilir; yaratıcı drama çalışmalarında katılımcılar kurgusal bir yaşantıyı deneyimlerken, oyunlarla ve oyunsu süreçlerle yaratıcılıklarını ve hayal güçlerini geliştirme olanağı bulurlar.

Rahat, eğlenceli, keyifli, zaman baskısından uzak bir ortamda daha yaratıcı olan çocukların (Senemoğlu, 1996), yalnızca özgür ve güvende hissettikleri durumlarda yaratıcılıklarının arttığ1 söylenebilir (Rogers'tan akt. Sungur, 1997). Bu süreçte kendiliğindenlik (spontanite) serbest bırakılır ve yaşamla bütünleştirilirse yaratıcılık ortaya çıkar (Adıgüzel, 2014). Kendilerini özgür ve güvende hisseden çocuklar daha özgün ve yaratıcı ürün ortaya koyarlar, duygularını daha sağlıklı ifade ederler. Yetişkinlerin çocuğun yaratıcıllğını geliştirmeleri için yapabilecekleri en önemli iş, çocuklara özgür ve güvenli ortamları sağlamak, spontan davranmalarına katkıda bulunmaktır. Bu katkı, düşünürken daha cesur davranan, yanılmayı ya da hata yapmayı göze alan çocukların yetişmesini olanaklı kılacaktır.

Öğrencilerin çok yönlü gelişmeleri, yaratıcıklarını ve hayal güçlerini kullanabilmeleri, farklı düzeylerde öğrenme becerileri edinebilmeleri ve duyuşsal gereksinimlerini karşılayabilmek için var olan öğretim yöntem ve tekniklerinden farklı bir deneyime sahip olmaları gerekmektedir (Gürkan, 2002). Yaratıcılığın ve hayal gücünün ortaya çıkmasını ve bireyin kendisini daha iyi ifade etmesini sağlayan bu süreçte oyunsu süreçleri, rol oynama ve doğaçlama gibi teknikleri kullanan yaratıcı dramanın bu gereksinimi karşılayacak en etkili yöntemlerden biri olduğu düşünülmektedir. Duyularını etkin bir biçimde kullanan, duygularını sağlıklı bir biçimde ifade eden çocuklar, gerçek potansiyellerini yaratıcı drama süreçleriyle ortaya çıkarabilirler. Çocuklar, kendilerini özgür ve güvende hissedecekleri söz konusu süreçlerde, önceki yaşantılarını göz önünde bulundurarak, yaratıcılıklarını ve hayal güçlerini olumsuz etkileyen durumları fark ederek bu konuda farkındalık geliştirebilirler, yaratıcı düşüncenin ortaya çıkması sürecinde önlerine çıkan engeller konusunda bilinçlenip, bu durumu önlemeye yönelik davranışlar geliştirebilirler.

\section{Araştırmanın Amacı}

$\mathrm{Bu}$ çalışmanın amacı, öğrencilerin yaratıcılığın önündeki okul, aile, çevre/toplum, teknoloji, kişisel özellikler gibi engelleri öğrenmelerinde ve bu konuda farkındalık kazanmalarında, yaratıcı dramanın rolünü incelemektir. Çalışma süresince öğrencilerin yaratıcılığın önündeki söz konusu engelleri yaşantıya dayalı atölye çalışmaları ile deneyimlemeleri, potansiyellerinin ve yaratıcılıklarının farkına varmaları ve kendilerini daha iyi ifade etmeleri amaçlanmıştır. Bu genel amaç göz önünde bulundurularak aşağıdaki sorulara yanıt aranmıştır:

1. Öğrencilerin yaratıcılık engellerini fark etmelerinde yaratıcı dramanın rolü nedir?

2. Öğrencilerden elde edilen ürünler yaratıc1lık engellerini fark etmelerinde nasıl etkili olmuştur? 


\section{Yöntem}

\section{Araştırma Modeli}

Çalışmada nicel ve nitel araştırma yöntemlerinin bir arada olduğu karma yöntem kullanılmıştır. Her iki yöntemin varsayımlarını, teorik altyapısını, veri toplama ve analiz süreçlerini benimseyen karma yöntemde, nicel ve nitel araştırmaların her ikisinin de güçlü yanlarından yararlanmak ve zayıf yanlarını aza indirmek amaçlanır (Creswell, 2014).

Araştırmada, problem durumları da göz önünde bulundurularak karma yöntemlerden birleşik desen (convergent) karma yöntemi kullanılmıştır. Çeşitleme (triangulation) olarak da bilinen birleşik desen en sık kullanılan karma yöntemlerden biridir ve nitel ya da nicel yöntemleri birlikte kullanmak, elde edilen verileri çeşitlendirmek, karşılaştırmak, bütünleştirmek için kullanılır. Birleşik desenlerde katılımcıların yaşantılarının ayrıntılı olarak ortaya konması amacıyla toplanan nicel ve nitel veriler birbirinden bağımsız olarak analiz edilir ve sonuçların birbirini destekleme düzeyi tartışılır (Creswell, 2014; Yıldırım ve Şimşek, 2016). Araştırmada, öğrencilerin yaratıcılığın önündeki engeller konusunda farkındalık düzeylerine yaratıcı dramanın etkisini belirlemek amacıyla kavram listeleri kullanılarak nicel veriler elde edilmiştir. Araştırmanın ikinci alt problemine ilişkin olarak ise öğrencilerden elde edilen ürünlerle nitel veriler elde edilmiştir. Veriler birbirinden bağımsız olarak analiz edilerek öğrencilerin yaratıcılı̆̆ın önündeki engellerin farkında olma düzeyleri ve yaratıcı dramanın bu süreçteki etkisi bulgulara ilişkin tartışmalarla ortaya konmuştur.

\section{Katılımcilar}

Çalışma grubunu 2012-2013 öğretim y1lında, bir devlet ortaokulunda öğrenim görmekte olan, daha önce yaratıcı drama yaşantısı olmamış, altıncı sınıf öğrencisi 16 erkek ve 10 kız çocuk oluşturmaktadır. Araştırma için planlanan süreç araştırma öncesinde öğrencilerle paylaşılmış ve çalışmaya katılım noktasında onayı alınan öğrenciler araştırmanın çalışma grubunu oluşturmuştur.

\section{Geçerlik ve Güvenirlik}

Nitel araştırmalarda farklı biçimlerde geçerlik ve güvenirliğin sağlanması amacıyla bazı yöntemler kullanılmaktadır (Creswell, 2007; Merriam, 2009; Yıldırım ve Şimşek, 2016). Bu araştırmada geçerliğin sağlanması amacıyla farklı veri toplama araçlarından yararlanılmış, elde edilen bulgular kavramsal çerçeve ile uyumlu bir şekilde sunulmuştur. Ayrıca kavram listesi ve açık uçlu sorular gibi veri toplama araçları uzman görüşüne sunularak, görüşler doğrultusunda son şeklini almıştır. Güvenirliğin sağlanması adına çalışmaya temel oluşturan kuramsal çerçeve, veri toplama süreci ve yöntemleri ayrıntılı olarak tanımlanmış; bulgular katılımcıların ifadelerinden doğrudan alıntılarla sunulmuştur.

\section{Uygulama Süreci}

Çalışmada yaratıcı drama bir yöntem olarak kullanılırken öğrencilerin yaratıcılıklarını engelleyen etmenler alanyazındaki yaratıcılık engelleri araştırılarak belirlenmiştir (Sungur, 1997; San, 2004; Fox ve Schirrmacher, 2012; Üstündağ, 2014; Kara ve Şençiçek, 2015). Sonrasında yaratıcılık engelleri göz önünde bulundurularak yaratıcı drama etkinlikleri kurgulanmış ve yaratıcı drama alanında bir uzmanın görüşüne başvurulmuştur. Uzman görüşü sonrasında gerekli düzeltmeler yapılmıştır. Araştırma süresince iletişim, uyum, güven, aile, eğitim, kişilik özellikleri, toplum/çevre, 
tabular, teknoloji, ekonomik koşullar konularının yaratıcılığa olan etkileri bağlamında kurgulanan yaratıcı drama etkinlikleri uygulanmıştır. Gerçekleştirilen 10 oturumda toplam 20 saat yaratıcı drama çalışması yapılmıştır. Oturumlarda yaratıcılığın önündeki engellerin fark edilmesiyle ve bu engellerin tartışılmasıyla ilgili kazanımlar belirlenmiştir.

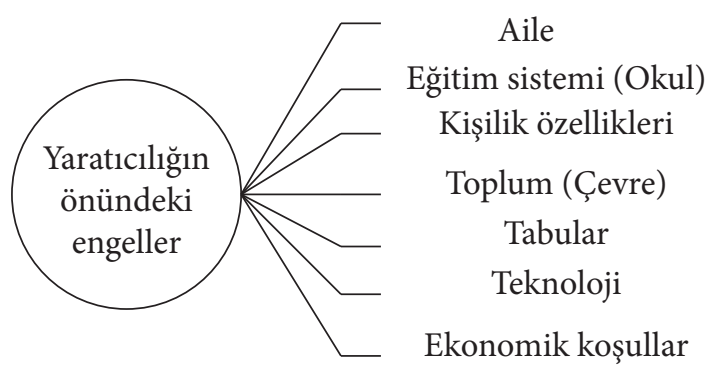

Şekil 1. Yaratıcılı̆̆ın Önündeki Engeller

\section{Veri Toplama Araçları}

Çalışmada nitel veri toplamak amacıyla, öğrenci ürünleri (mektup, poster ve afiş tasarımları, öğrencilerin duygu, düşünce ve çalışmalarla ilgili bilgilerini ölçen yazılı ürünler), öğrencilere her oturum sonunda yöneltilen açık uçlu sorular kullanılmıştır. Öğrencilere yöneltilen açık uçlu sorular aşağıda sunulmuştur:

- Bu çalışmada en çok hangi yönünün geliştiğini düşünüyorsun?

- Bu çalışmada yaptığın en yaratıcı şey neydi?

- Bu çalışmada neler ögrendiğini düşünüyorsun?

Nicel veri toplamak amacıyla üzerinde 10 farklı kavramın (yaratıcılık, grup çalışması, hayal gücü, uyum, iletişim, birliktelik, güven, özgürlük, öğrenme, hoşgörü) bulunduğu kavram listesi kullanılmıştır. Kavram listesindeki maddeler yaratıcı dramanın genel amaçlarını (Adıgüzel, 2014) işaret eden, öğrencilerin en sık gözlemledikleri durumları ifade etmektedir.

\section{Verilerin Toplanması ve Analizi}

Yaratıcı drama atölyelerinin uygulanması sürecinde açık uçlu sorular ve kavram listeleri her çalışmanın sonunda öğrenciler tarafından yanıtlanmıştır. Toplanan verilerle öğrencilerin yaratıcılık engeli olarak tanımlanan durumları kavrayıp kavramadıklarını ve ortaya çıkan ürünlerin kazanımlarla ne kadar ilişkili olduğunu ölçmek hedeflenmiştir. Öğrenci yanıtları ilgili araca girilerek ortaya çıkan analizler tablo biçiminde sunulmuştur. Araç öğrencilerin ilgili kavramı hangi sıklıkla işaretlediklerini ortaya koymak amacıyla tercih edilmiştir. Nitel verilerin analizinde ise betimsel analiz kullanılmıştır. Betimsel analiz sürecinde verilerden elde edilen bulgular daha önceden belirlenen temalara göre düzenlenir (Yıldırım ve Şimşek, 2008). Bu bağlamda ortaya çıkan kategoriler alanyazına uygun olarak belirlenen temalar altında toplanmış ve ortaya çıkan bulgular tablolar biçiminde sunulmuştur. 


\section{Bulgular}

\section{Araştırmanın Birinci Alt Problemine İlişkin Bulgular}

\section{Kavram Listesiyle Elde Edilen Bulgular}

Öğrencilere her çalışmanın sonunda üzerinde "yaratıcılık, grup çalışması, özgürlük, birliktelik, hoşgörü, uyum, güven, iletişim, öğrenme, hayal gücü” kavramlarının yazılı olduğu kâğıtlar verilmiş, seçeneklerden hangilerinin daha çok geliştiğini düşündükleri sorulmuş, en çok üç seçeneği işaretlemeleri söylenmiştir.

Verilen yanıtların frekans ve yüzde dağılımları Tablo 1'de sunulmuştur.

Tablo 1. Kavram listesi ile elde edilen yanıtlara ilişkin bulgular

\begin{tabular}{lll}
\hline & $\mathrm{f}$ & $\%$ \\
\hline Yaratıcılık & 151 & $25,6 \%$ \\
Grup çalışması & 85 & $14,4 \%$ \\
Hayal gücü & 76 & $12,9 \%$ \\
Uyum & 59 & $10,0 \%$ \\
İletişim & 57 & $9,7 \%$ \\
Birliktelik & 43 & $7,3 \%$ \\
Güven & 41 & $7,0 \%$ \\
Özgürlük & 39 & $6,6 \%$ \\
Öğrenme & 25 & $4,2 \%$ \\
Hoşgörü & 13 & $2,2 \%$ \\
\hline
\end{tabular}

Öğrencilerin araştırma süresince yanıtladıkları 198 çoklu yanıt ölçeği ve dağılımı tabloda görülmektedir. Elde edilen verilere göre "Yaratıcılık" seçeneği \%25,6 yüzdesiyle ve $151 \mathrm{kez}$ işaretlenme sayısıyla çalışma süresince en çok tercih edilen alan olmuştur. Öğrenciler en çok gelişen alanlarını sırasıyla Yaratıcılık, Grup Çalışması, Hayal Gücü, Uyum, İletişim, Birliktelik, Güven, Özgürlük, Öğrenme ve Hoşgörü olarak tercih etmişlerdir.

Yaratıcılık seçeneğinin en çok tercih edilen seçenek olması, yaratıcılık engellerinin öğrenciler tarafından fark edildiğinin bir göstergesi olarak değerlendirilebilir. Yukarıdaki bulgular göz önünde bulundurulduğunda çalışmada yöntem olarak kullanılan yaratıcı dramanın, çalışma süresince öğrenme süreçlerine olumlu katkıda bulunmuş olduğu söylenebilir.

\section{Betimsel Analiz Sonucu Elde Edilen Bulgular}

Çalışma süresince her oturum sonunda etkinliklerle ve süreçle ilgili duygu, düşünce ve tutumları ölçmek amacıyla öğrencilere açık uçlu sorular yöneltilmiştir. Verilen yanıtlardan elde edilen bulgular, soruların ve öğrenci yanıtlarının bulunduğu tablolar biçiminde sunulmuştur.

Öğrencilerin sorulara verdikleri yanıtlar a)Yaratıcı dramanın genel amaçları (Adıgüzel, 2014), b) Yaratıcılık ve yaratıcılık engelleri, c)Çalışmaların kazanımları göz önünde bulundurularak kodlanmış ve kategorilere ayrılmıştır.

Söz konusu ölçütlerden yaratıcı dramanın genel amaçları Adıgüzel'e (2014) göre aşağıdaki gibidir; 
a. Yaratıcılığ ve hayal gücünü geliştirme,

b. Kendini tanıma, gerçekleştirme ve başkalarıyla iletişim becerisini geliştirme,

c. Demokratik tutum ve davranış geliştirme,

d. Estetik davranışlar geliştirme,

e. Eleştirel ve bağımsız düşünebilme becerisi geliştirme,

f. İşbirliği yapabilme-birlikte çalışma becerisi geliştirme,

g. Sosyal duyarlik yaratma,

h. Duygunun sağlıklı bir biçimde boşalımı ve kontrolü,

i. Dil gelişimi, sözel ve sözel olmayan ifade becerisi geliştirme.

Öğrencilerin “Bu çalışmada en çok hangi yönünün geliştiğini düşünüyorsun?” sorusuna verdikleri yanıtlara ilişkin bulgular Tablo 2'de temalar ve öğrencilerin yanıtlarından doğrudan alıntılarla sunulmuştur:

\section{Gelişim Teması}

Tablo 2. Uygulama sürecinde öğrencilerin gelişim alanları

\begin{tabular}{lll}
\hline & $\mathrm{f}$ & $\%$ \\
\hline İletişim becerileri & 17 & 48,57 \\
Yaratıcılık ve hayal gücü & 10 & 28,57 \\
Grup çalışmasi/birlikte çalışma & 4 & 11,43 \\
Eleştirel ve bağımsız düşünme & 4 & 11,43 \\
\hline
\end{tabular}

Ö4. Arkadaşlarımla iletişim kurma becerimin geliştiğini düşünüyorum.

Ö7. Arkadaşlarımla uyum içinde hareket ettim.

Ö8. Beden dilimi kullandım ve çevremdekilerle daha iyi iletişim kurdum.

Ö13. Fikir üretme ve hayal gücümün geliştiğini düşünüyorum.

Ö18. Rol yapma ve yaratıcılı̆̆ımın geliştiğini düşünüyorum.

Ö21. Sinıftakilerle birlikte dayanışma içinde çalıştım.

Elde edilen bulgular ışığında, soruya verilen yanıtların yaratıcı drama alanyazınında belirtilen amaçları işaret ettiği görülmektedir. Öğrenciler çalışmalardaki değerlendirme aşamalarında birlikte çalışma, beden dilini kullanma, arkadaşlarına güvenme, uyumlu olma, yaratıcı drama tekniklerini kullanma (rol oynama, doğaçlama), oyun oynama gibi becerilerinin geliştiğini ve bu becerileri gerçek yaşamlarında daha iyi kullandıklarını ifade etmişlerdir.

Büyük grupla ya da küçük gruplarla yapılan tartışma, soru sorma ve sorulara yanıtlar arama, bir konu hakkında beyin firtınası yapma ve düşünmeye yönelten sorular sorma yaratıcılı̆̆ı olumlu yönde etkileyen yöntem ve tekniklerdir. Yaratıcı drama süreçlerinde kendilerini rol içinde ve güvenli bir ortamda ifade eden öğrenciler rol oynama, doğaçlama, toplantı düzenleme gibi canlandırma teknikleriyle üst düzey düşünme becerilerini geliştirerek eleştirel ve bağımsız düşünme olanağ1 bulmuşlardır. 
“Bu çalışmada yaptığın en yaratıcı şey neydi? ” sorusuna verilen yanıtlar öğrencilerin gerçek yaşamda yapamadıkları, karşılaştıkları engeller nedeniyle kendilerini ifade edemedikleri durumları ortaya koymaktadır. Öğrenci yanıtları temalar ve yanıtlardan sunulan alıntılarla Tablo 3 'te verilmiştir:

\section{Yaratıcı Etkinlikler Teması}

Tablo 3. Uygulama sürecinde ögrencilerin yaratıcılık algıları

\begin{tabular}{lll}
\hline & $\mathrm{f}$ & $\%$ \\
\hline Canlandırma etkinlikleri (rol oynama, doğaçlama, donuk imge, fotoğraf anı) & 32 & 59,26 \\
Nesneyi farklı bir şeye benzetme/görevi dışında kullanma & 8 & 14,81 \\
Beden dilini ve sesi kullanma & 8 & 14,81 \\
Oyun oynama & 6 & 11,11 \\
\hline
\end{tabular}

Ö3. Atasözlerinden uzun bir drama çalışması yapmak.

Ö6. Bilgisayarda oynayan çocuğu canlandırmak.

Ö8. Okuldan kaçma canlandırması yapmak.

Ö9. Öğretmenin dăğttı̆̆ küçük kâğıtlarla roller yapmak.

Ö11. Kalem kutudan kumanda yapmak.

Ö13. Kalemliği psp olarak kullanmak.

Ö17. Masa ve sandalyenin çocuk olması.

Ö19. Canlandırmada farklı ses tonu kullanmak.

Ö20. Rol yaparken sesimi değiştirmek ve yeni ses tonu kullanmak.

Ö22. Kurt-kuzu ve don-ateş oyunlarını daha iyi oynadım.

Ö23. Davul zurna 1-2-3 oyununu oynamak.

Ö24. Kurt olup kuzuyu yakalamak.

Iraksak düşünme yaratıcılığın ortaya çıkmasında ve öğrencilerin kendilerini yaratıcı bir biçimde ifade etmelerinde vazgeçilmez bir yöntemdir (Baykal, 2009). Çalışmanın başlangıcında nesneleri kendi görevleriyle kullanan (yakınsak düşünen) öğrenciler, zamanla nesneleri farklı şeylere benzeterek amaçları dışında kullanmışlardır.

Öğrenciler canlandırma aşamalarında farklı rollere girme (zengin olmak, yetişkin olmak, müdür olmak, masa ve sandalyenin çocuk olması, teyze rolüne girmek, anne olmak, ağaç olmak gibi) ifadelerle yaratıcı düşünceyi/yaratıcılığı açıklayan durumları ifade etmişlerdir.

Soruya verilen yanıtlardan bir diğeri ise canlandırma aşamasındaki rol oynama ve doğaçlama çalışmalarıdır. Canlandırma aşamasıyla ilgili verilen "bir cümleyle uzun bir canlandırma yapmak, okuldan kaçma canlandırması, rol yaparken anne olmak” gibi yanıtlar öğrencilerin rol oynadıkları, doğaçlama yaptıkları süreçleri yaratıcı bulduklarını, bu süreçlerde kendilerini daha nitelikli ifade ettiklerini göstermektedir. Elde edilen bir diğer bulgu ise öğrencilerin bedenlerini ve seslerini kullanmalarını (farklı ses tonu kullanmak, beden dilini kullanmak, rol yaparken sesimi değiştirmek, rol yaparken yeni bir ses tonu kullanmak) yaratıcı bulmalarıdır. 
Çalışmanın kazanımlarını ortaya koymak amacıyla sorulan "Bu çalışmada neler öğrendiğini düşünüyorsun?" sorusuna verilen yanıtlar, yaratıcılığ engelleyen etmenleri gösterirken belirlenen kazanımların gerçekleştiğini ortaya koymaktadır. Öğrencilerin soruya verdiği yanıtlar, atölye başlıklarına göre oluşturulan temalar ve yanıtlardan alıntılanan ifadelerle Tablo 4'te sunulmuştur:

\section{Dramayla Öğrenme Teması}

Tablo 4. Öğrencilerin yaratıcılı engelleri konusunda öğrendikleri bilgiler

\begin{tabular}{lll}
\hline & $\mathrm{f}$ & $\%$ \\
\hline Uyum ve Güven & 12 & 19,67 \\
Toplum ve çevre & 8 & 13,11 \\
Kişilik özellikleri & 8 & 13,11 \\
Yaratıcılık ve engelleri & 8 & 13,11 \\
İletişim & 7 & 11,48 \\
Teknoloji & 5 & 8,20 \\
Tabular & 4 & 6,56 \\
Eğitim & 3 & 4,92 \\
Aile & 3 & 4,92 \\
Ekonomik koşullar & 3 & 4,92 \\
\hline
\end{tabular}

Ö2. Insanlara güven duymayı öğrendim.

Ö7. Liderini bul oyununda birlikte hareket etmeyi öğrendim.”

Ö8. Başkalarının yaratıcılığını engellememeyi öğrendim. ,

Ö10. Çevrenin yaratıcılı̆̆ımızı, etkilediğini, çevreye duyarlı olmayı öğrendim.

Ö12. Hata yapmaktan korkmamayı ögrendim.

Ö13. Yaratıcılı̆̆ı engelleyen durumları ve yaratıcılı̆̆ öğrendim.

Ö16. Rol oynamayı ve doğaçlama yapmayı öğrendim.

Ö18. Göz teması kurmayı ve beden dilimi kullanmayı öğrendim.

Ö19. Teknolojinin yararlarını ve zararlarını, teknolojik araçların yaratıcılı̆̆ etkilediğini ögrendim.

Ö22. Atasözü ve tabunun anlamını, bazı atasözlerinin tabu olduğunu ve tabuların yaratıcılı̆̆ engellediğini öğrendim.

Ö25. Ailenin ve eğitim sisteminin yaratıcılı̆̆ı etkilediğini öğrendim.

Ö26. İnsanları parasına göre karşılaştırmamayı ve ekonomik koşulların yaratıcılı̆̆ etkilediğini ögrendim.

Teknolojik bilgi yaratıcılığı farklı biçimlerde, hatta belki de sonsuz biçimde harekete geçirir. Bu durum olumlu olabileceği gibi olumsuz da gerçekleşebilir (Çotuksöken, 2007). Öğrenci yanıtları incelendiğinde, teknoloji ve ekonomiyle ilgili çalışmalarda öğrencilerin yaratıcılığı engelleyen etmenleri farklı biçimlerde tanımladıkları; bu etmenleri bazen bir engel olarak görürken bazen de yaratıcılığı olumlu etkileyen durumlar olarak tanımladıkları görülmektedir. Öğrencilerin bir bölümü ekonominin ve teknolojinin yaratıcılı̆̆ 1 olumlu etkilediğini ifade ederken kimi öğrenciler de hem olumlu hem de olumsuz etkilerinin olduğunu ifade etmişlerdir. 
Oyun ve oyunsu süreçler yaratıcı dramada özellikle hazırlık-ısınma aşamasında kullanılır. "Bu çalışmada yaptı̆̆ın en yaratıcı şey neydi?" sorusuna verilen yanıtlar arasında çalışmada kullanılan oyunların sıklıkla bulunduğu ve öğrencilerin çalışmada kullanılan oyunlardan en az birini soruları yanıtlarken kullandıkları görülmektedir. Bu durum öğrencilerin oyunları yaratıcı bulduklarını, oyunsu süreçlerin yaratıcılıklarını ve hayal güçlerini geliştirdiği yönünde düşüncelere sahip olduklarını düşündürebilir.

\section{Araştırmanın İkinci Alt Problemine İlişskin Bulgular}

\section{Öğrenci Geribildirimleriyle Elde Edilen Bulgular}

Çalışma süresince öğrencilerin yanıtladıkları boşluk doldurma soruları, mektuplar ve günlükler ile poster ve afiş tasarımları nitel veri olarak toplanmış ve yorumlanmıştır. Yorumlar neticesinde elde edilen bulgular aşağıdaki gibidir:

Birinci oturum sonunda doldurulan formda öğrencilerin iletişimi engelleyen durumlara verdikleri yanıtlar bulunmaktadır. Elde edilen bulgular kazanımlara ulaşıldığını ve öğrencilerin iletişimin önündeki engeller konusunda bilgi sahibi olduklarını göstermektedir. Öğrencilerin "Sizce iletişimi engelleyen durumlar nelerdir? ” sorusuna verdikleri yanıtlardan alıntılanan bulgular așağıda sunulmuştur:

Ö3. Göz teması kurmamak

Ö5. Yardımlaşmamak

Ö7. Dayanışma sağlamamak

Ö8. Birlik olmamak

Ö10. İzinsiz konuşmak

Ö12. Kız erkek ayrımı yapmak

Ö15. İnsanlarla konuşurken sesimizi yükseltmek

Ö16. İnsanlarla göz iletişimi kurmamak

Ö17. Arkadaşlarımızın sözünü kesmek

Ö18. Birbirimize saygısılılk yapmak

Ö19. Arkadaşlarımızı dinlememek

Ö22. Bă̆ırmak

\section{Ö23. Beden dili kullanmamak}

\section{Ö25. Söz almadan konuşmak}

\section{Uyum Kavramına İlişsin Öğrenci İfadeleri}

Yaratıcı drama çalışmalarında öğrenciler bireysel ya da grup olarak uyum ve dayanışma içinde etkinlikleri gerçekleştirirler. Uyum çalışmaları öncesinde öğrencilere sorulan "Sizce uyum nedir ve uyumu hangi sözcüklerle ifade edersiniz?" sorusuna öğrencilerin verdikleri yanıtların bir bölümü çalışmada bulunan etkinlikleri, diğer bölümü ise yaşamlarında kendileri için uyumu işaret eden durumları göstermektedir. Bazı yanıtlar da yaratıcı drama sürecinde oynanan oyunları içermektedir. Öğrencilerin bu soruya ilişkin yanıtları aşağıdaki gibidir: 


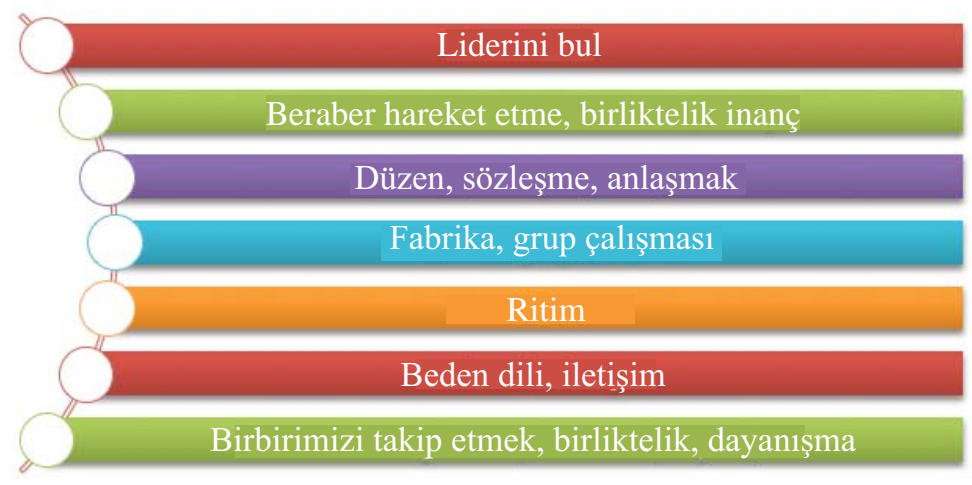

Şekil 2. Uyum kavramına ilişkin öğrenci ifadeleri

\section{Güven Kavramına İlişkin Öğrenci İfadeleri}

Hem yaratıcılık süreci hem de yaratıcı drama öğrencilerin kendilerini özgür ve güvende hissetmelerine gereksinim duyar. Yaratıcı düşünme sürecinin spontan bir biçimde gerçekleşebilmesi ve yaratıcı drama etkinliklerinin başarıyla ilerleyebilmesi için olmazsa olmaz bir kavram olan güvene ilişkin öğrenciler öğrencilerin yanıtlarından alıntılanan ifadeler aşağıda sunulmuştur:

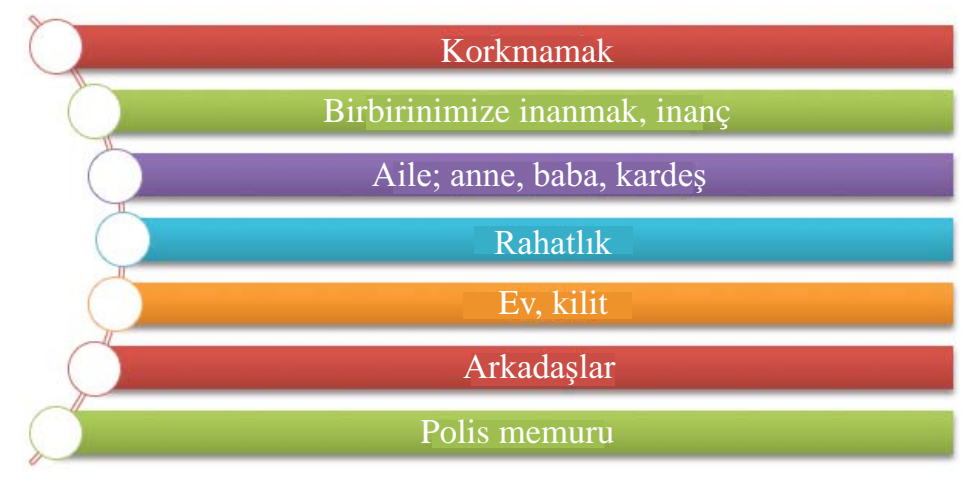

Şekil 3. Güven kavramına ilişsin ögrenci ifadeleri

Dördüncü oturumda “Okulda yaratıcı olamıyorum, çünkü...” ifadesine verilen yanıtlar öğrencilerin okul kavramıla ilgili düşüncelerini ifade etmektedir. Yanıtlar, öğrencilerin okulu ve okulun içinde bulunan idarecileri, öğretmenleri, öğrencileri yaratıcılıklarının önünde bir engel olarak gördüklerini, aynı zamanda okulun yalnızca bir bina olduğunu, yaratıcılıklarını gösterecekleri bir yaşam alanından çok uzakta bulunduğunu ortaya koymaktadır. Öğrencilerin soruya verdiği yanıtlardan alıntılanan ifadeler aşağıdaki gibidir:

Ö4. Okulumuzda elektronik kitap yok, okulun yapısı yaratıcı olmamız için uygun değil.

Ö6. Okulda özgür olamıyorum, okulda yeteri kadar atölye yok, bazı ögretmenler alt bahçeye çıkarmıyor.

Ö9. Okulda yeterli alan yok, okulda kendimize ait zamanımız yok. 
Ö10. Ya ögretmenler klzıyor ya da çalışacak yerin olmuyor, resim atölyesi, beden salonu gibi yerler yeterli olmuyor, arkadaşlarım yaratıcılı̆̆ımı engelliyor, okulda özgür olamiyorum.

Ö13. Okul binası yeterli değil, oyun oynamak için yer yok.

Ö20. Öğretmenler ve arkadaşlarım yaratıcı olmamı engelliyor, kurallar ve yasaklar var.

Ö24. Burası özel okul gibi büyük değil, etkinlik saatimiz yok, basketbol, voleybol, futbol, tenis ve yüzme gibi yerler yok, okul bahçesinde istediğimiz gibi özgürce oyun oynayamıyoruz.

\section{Mektup, Günlük ve Afişlerden Elde Edilen Bulgular}

Öğrencilerin yazmış oldukları mektuplar aşağıdaki durumları içermektedir.

- Charlie isimli yavru aslanın daha yaratıcı ve kendisini ifade eden bir birey olmak için ailesinden istekleri,

- Ahmet karakteri hakkında yazılan yaratıcılığı olumsuz etkileyen kişilik özellikleri,

- Öğrencilerin oyun alanlarını göz önünde bulundurarak belediye başkanına yazdıkları mektuplar,

- Çevre ve toplumun yaşamlarına ve yaratıcılıklarına olumsuz etkileri,

- Göktuğ rolünde Kerem isimli öğrenciye yazdıkları, ekonomik durumların yaratıcılığa olumsuz etkilerini içeren metinler.

Öğrencilerin yazmış oldukları günlükler incelendiğinde; teknolojik araçları çok sık kullanmaktan duydukları pişmanlıklar ve aileleriyle bu soruna bir çözüm bulma istekleri gözlemlenmektedir. Öğrenci ifadelerinden, öğrencilerin teknolojiyi yaratıcılıklarını olumsuz etkileyen bir araç olarak görmedikleri, kendileri için asıl sorunun teknolojiyi gereğinden fazla kullanmaları olduğu görülmektedir. Yazılan mektuplar ve günlükler, çizilen/tasarlanan afişler incelendiğinde öğrencilerin yaratıcıllğı engelleyen etmenleri yazılarına ve çizimlerine yansıttıkları gözlemlenmektedir.

\section{Tartışma, Sonuç ve Öneriler}

Çocukların yaşamında ev, okul, aile, cinsiyet rolleri, toplum kültür ve gelenek (Sungur, 1997; Fox ve Schirrmacher, 2012); uyguculuk, bireyin kişisel rahatına düşkünlügü̈, içsel özgürlükten yoksun olma, dünyada pek az kişinin yaratıcı olduğu düşüncesi (San, 2012); yakınsak düşünme ve yetişkinlerin çocuk yetiştirme biçimleri (Üstündağ, 2014) gibi yaratıcı olmalarını engelleyen pek çok engel bulunmaktadır. Bu engellerin bilinmesi ve ortadan kaldırılması yaratıcılığın ortaya çıkmasını sağlamanın ilk adımı olabilir ve bireylerin de davranışlarını olumlu anlamda değiştirebilir (Dursun ve Ünüvar, 2011). Araştırma süresince öğrenciler yaratıcılıklarının önündeki engelleri fark ettiklerini ve gerçek yaşamlarında bu farkındalıkla hareket ettiklerini ifade etmişlerdir. Araştırmada elde edilen bulgular yaratıcı drama yönteminin yaratıcı çocuklar yetiştirilmesinde, yaratıcılığın önündeki engellerin aşılmasında ya da bu engellerin çocuklar tarafından fark edilmesinde etkili olduğunu ortaya koymaktadır.

Yaratıcılık engellerinin fark edilmesi konusunda ailelere, öğretmenlere ve yetişkinlere önemli görevler düşmektedir (Sungur, 1997; Dursun ve Ünüvar, 2011; San, 2012; Fox ve Schirrmacher, 2012; 
Üstündağ, 2014). Araştırmada elde edilen sonuçlar teknolojinin, kitle iletişim araçlarının ve sosyal medyanın ailelerin, öğretmenlerin ve toplumun yaratıcılık engelleri konusunda bilinçlendirilmesinde önemli bir rol oynayabileceğini göstermektedir.

Yaratıcılık dar kapsamlı, yalnızca bir sözcük değil bir süreç olarak değerlendirmelidir; bu süreç hem soyut, bilişsel ve duyuşsal bir alt yapıyı hem de somut işlemleri kapsar (Tekin Bender, 2014). Yaratıcı drama ve yaratıcılık benzer özellikleriyle birlikte birbirine hizmet eder. Araştırma süresince elde edilen bulgular katılımcıların rolde ve kurguda, spontan, yaratıcı bir biçimde kendilerini ifade etiklerini göstermektedir.

Çocukların yaratıcı birer birey olmaları için okullara ve eğitim sistemine önemli görevler düşmektedir (Kara ve Şençiçek, 2015). Bu görevlerin yerine getirilmesi sürecinde öğretmen merkezli ve ezbere eğitim öğrencilerin önünde engel olarak bulunmaktadır. Yaratıc1lı engellerinin fark edilmesi sürecinde bu durumlar göz önünde bulundurulabilir. Ayrıca çocukların yaratıcı birer birey olmaları yolunda öğretmenlerin de yaratıcı olmaları ve öğrencileri yönlendirmeleri gerekmektedir.

Çalışmanın, öğrenci ürünleri bakımından zengin bir çeşitliliğe sahip olduğu düşünülmektedir. Elde edilen bulgular, öğrencilerin yaratıcılığı engelleyen etmenler konusunda farkındalıklarının arttığını göstermektedir. Açık uçlu sorulara verilen yanıtlar incelendiğinde öğrencilerin yaratıcılık engellerinin neler oldukları konusunda fikir sahibi oldukları görülmektedir. Yaratıcı drama yönteminin ve tekniklerinin öğrencileri yaratıcılıklarını kullanmada ve kendilerini ifade etmekte olumlu yönde etkilediği gözlemlenmektedir. Öğrenciler canlandırmalarda farklı rollere girmelerinin çok yaratıcı olduğunu ve bu durumda kendilerini iyi hissettiklerini yazılı geribildirimleriyle ifade etmişlerdir. Öğrencilerin anne, baba, öğretmen, müdür ya da arkadaşlarından birinin rolüne girmelerinin, sorunlara onların gözlerinden bakmalarının duygudaşlık becerilerini geliştirdiği ve karşılaştıkları sorunlarda çözüme ulaşmalarını kolaylaştırdığ 1 gözlemlenmiştir.

Sıra dışı davranış ve ürünlerle tanımlanan yaratıcılık için özgünlük yeterli olmasa da gerekli bir özelliktir. Yaratıcı düşünce sıklıkla rastlanan oluşumlarda değil özgün süreçlerde kendini gösterir (Baykal, 2009). Öğrenciler araştırma süresince özgün ürünler (canlandırma etkinlikleri; rol oynama, doğaçlama ve oyunlar, yazılı ürünler; mektuplar, günlükler, afişler) ortaya koyarak ve kendilerini özgün bir biçimde ifade ederek yaratıcılıklarını kullanmışlardır.

Araştırma bulgularından yola çıkılarak aşağıdaki önerilerde bulunulabilir:

Çoğunlukla kendilerinden uyumluluk ve yakınsak düşünme beklenen okul ortamlarında bulunmak zorunda kalan öğrenciler (Fox ve Schirrmacher, 2012), çalışma süresince yaratıc1lıklarını engelleyecek biçimde tasarlanan okul ortamlarını (Ataman, 1995; Üstündağ, 2014) ve eğitim sistemini kendilerini kisitlayan, rahat hareket etmelerini engelleyen, kendilerini ifade etmelerine engel olan mekânlar ve süreçler olarak tanımlamışlardır. Düş gücü yüksek ve yaratıcı öğrenciler daha esnek ve kendilerini nitelikli bir biçimde ifade edecekleri öğrenme mekânlarına ve süreçlerine gereksinim duymaktadırlar. Tüm bunların gerçekleşmesi amacıyla okullar öğrencilere daha fazla hareket edebilecekleri, oyun oynayabilecekleri, gerçek yaşama olabildiğince yakın mekânlar biçiminde tasarlanabilir.

Yapılandırmacı söylemlerle geliştirilen öğretim programlarının, yaratıcılık ifadeleri içermesine ve öğrenci merkezli olduğu iddia edilmesine karşın öğretmen merkezli bir eğitim sistemini gerektirmesi öğrencilerin yaratıcılıklarını engellemektedir. Öğrencilerin yaratıcılıklarının 
geliştirilmesi/ortaya çıkarılması amacıyla öğrenciyi merkeze alan programlar geliştirilebilir, öğretim programlarındaki yaratıcılığı geliştiren/ortaya çıkaran içerikler artırılabilir.

Çalışma süresinceöğrencilerin engel olarak gördüklerive bu yönde geribildirimde bulundukları aileler, öğretmenler ve okul yöneticileri yaratıc1lık engelleri konusunda bilinçlendirilebilir bu engellerin ortadan kaldırılmasında olumlu sonuçlar yaratabilir.

Teknoloji bir yanıyla öğrenciyi oyundan ve hayal gücünden uzaklaştırarak yaratıcılığ engelleyen, diğer yanıyla eğitsel bilgisayar oyunlarıyla ya da dijital uygulamalarla yaratıcıllğı olumlu etkileyen bir alandır. Yaratıcı drama çalışmaları yapılırken bu durumun göz önünde bulundurulması, teknolojinin olumlu ve olumsuz yanlarının yaratıcılığa etkisinin ele alınması sağlanabilir.

Araştırmada elde edilen bulgular, öğrencilerin engellerle karşılaştıkları durumları yazarak daha rahat ifade ettiklerini göstermektedir. Yaratıcılığı engelleyen durumların öğrenciler tarafindan fark edilmesi sürecinde yaratıcı dramanın yaratıcı yazma etkinlikleri etkili bir biçimde kullanılabilir. Yaratıc1 drama süreçlerinde görsel, işitsel araç ve gereçlerin kullanılması öğrencilerin sürece ilgilerinin artmasını sağlayabilir. Bu tür çalışmalarda teknoloji olanakları daha sık kullanılabilir ve öğrencilerin sürece etkin katılımı sağlanabilir.

Tüm bu sonuçlara bağlı olarak yaratıcılığın önündeki engelleri kaldırmak amacıyla söz konusu engellere öğretim programlarında yer verilebilir. Anne-babalara, öğretmenlere, yetişkinlere yaratıcılık engellerinin aşılması konusunda seminerler düzenlenebilir. Araştırma sonuçları çocukların yaratıcı drama yoluyla rolde ve kurgusal biçimde kendilerini daha iyi ifade ettiklerini, Yaratıcılıklarının önündeki engelleri fark ettiklerini ortaya koymaktadır. Bu bağlamda çocukların yaratıcı drama ile temas etmelerini sağlayacak olanaklar oluşturulabilir ve çocuklar sanat yoluyla kendilerini daha nitelikli ifade edebilirler. 


\section{Kaynakça}

Adıgüzel, Ö. (2014). Eğitimde yaratıcı drama (6. Baskl), Ankara: Pegem Akademi Yayıncılık.

Ataman, A. (1995). Eğitim sürecinde yaratıcılık. Ayşegül Ataman (Ed.). Yaratıcıllk ve eğitim içinde (s. 105128). Türk Eğitim Derneği XVII. Eğitim Toplantısı. Ankara: Türk Eğitim Derneği Yayınları.

Baykal, A. (2009). Yaratıcılık: Eğilimi ve eğitimi. Öğrenme ve Öğrenme Bozuklukları II. Eğitim Psikolojisi Sempozyumu (s. 34-57). İstanbul: Kültür Üniversitesi.

Burnard, P. ve White, J. (2008). Creativity and performativity: Counterpoints in British and Australian education. British Educational Research Journal, 34 (5), 667-682.

Creswell, J.W. (2007). Qualitative inquiry \& research design: Choosing among five approaches. California: Sage.

Creswell, J. W. (2014). Research design: Qualitative, quantitative and mixed methods approaches. California: Sage.

Çotuksöken, B. (2007). Dil ve yaratıc1lk. Dil ve Yaratıcılık Dergisi, 1, 7-11.

Dursun, M. A. ve Ünüvar, P. (2011). Okulöncesi eğitim döneminde yaratıc1lığı engelleyen durumlara ilişkin ebeveyn ve öğretmen görüşlerinin incelenmesi. Mehmet Akif Ersoy Üniversitesi Eğitim Fakültesi Dergisi, $11(21), 110-133$.

Fox, J. E. ve Schirrmacher, R. (2012). Sanat ve yaratıcılı̆̆ın gelişimi (7. Basımdan Çeviri). Nobel Yayıncılık.

Gardner, H. (2009). Çoklu zeka kuramı, yaratıcılık, gelecek için beş akıl. Birinci Uluslararası Yaşayan Kuramcılar Konferansı: Howard Gardner. Burdur: Mehmet Akif Ersoy Üniversitesi Yayını.

Gürkan, T. (2002). Bireyin çok yönlü gelişimi. Eğitim Sürecinde Zekâ ve Yaratıcı Düşünme Çalıştayı (s. 3033). Ankara: Milli Eğitim Basımevi.

Herrmann, N. (2003). Bütünsel beyin. Mehmet Öner (Çev.). İstanbul: Hayat Yayınları.

Kara, Ş. ve Şençiçek, S. (2015). Yaratıcı çocuk yetiştirmede problemler ve çözüm önerileri. Adnan Menderes Üniversitesi Ĕgitim Fakültesi Ĕgitim Bilimleri Dergisi, 6 (2), 90-97.

May, R. (2010). Yaratma cesareti (12. Baskı). A. Oysal (Çev), İstanbul: Metis Yayınları.

Merriam, S. B. (2009). Qualitative research: A guide to design and implementation. Jossey Bass: Wiley.

Parsı1, Ü. (2012). Sanatta yaratıcılık. İstanbul: An Yayıncılık.

Püsküllüoğlu, A. (2012) Türkçe sözlük. Ankara: Arkadaş Yayınevi.

Robinson, K. (2008). Yaratıcılık aklın sınırlarını aşmak (2. Baskı). Nihal Geyran Koldaş (Çev.). İstanbul: Kitap Yayınevi.

San, İ. (2003) Sanat eğitimi kuramları (2. Baskı). Ankara: Tan Yayınları.

San, İ. (2004). Sanat ve ĕgitim (3. Baskı). Ankara: Ütopya Yayınları.

San, İ. (2012). Yaratıcılıkta temel kavramlar. Ali Öztürk (Ed.) Okulöncesinde yaratıcllık içinde (s. 3-15). Eskişehir: Anadolu Üniversitesi Yayınları.

Senemoğlu, N. (1996). Yaratıcıllk ve öğretmen nitelikleri. Yaratıcılık ve Eğitim Paneli, Kara Harp Okulu, Ankara. (http://yunus.hacettepe.edu.tr/ n.senem/makaleler/yaratici.htm).

Sungur, N. (1997). Yaratıcı düşünce (2. Baskı). İstanbul: Evrim Yayınları.

Tekin Bender, M . (2014). Yaratıcılık, kişilik ve sanatsal yaratma üzerine. Erciyes Sanat Dergisi, 1, 20-30.

Üstündağ, T. (2014). Yaratıclı̆̆a yolculuk (6. Bask1). Ankara: Pegem Akademi Yayıncılık.

Yıldırım, A. ve Şimsek, H. (2016). Sosyal bilimlerde nitel araştırma yöntemleri. Ankara: Seçkin. 